\author{
Włodzimierz Andrzej Bednarek \\ dr hab. inż. \\ Politechnika Poznańska, Wydział Budownictwa i Inżynierii Środowiska, \\ Zakład Budowy Mostów i Dróg Kolejowych \\ włodzimierz.bednarek@put.poznan.pl
}

DOI: 10.35117/A_ENG_16_02_02

\title{
The problems of arising vertical irregularities in operating railway track
}

\begin{abstract}
Arising during railway track structure operating the geometrical irregularities of track in vertical plane are the additional sources of interaction between the trains and track. These irregularities have got an unintentional character (arising in random way during track operating, e.g. irregularities in track, change of track geometrical parameters or inhomogeneity of track support) and intentional character (arising e.g. during railway track lifting by VSS plate). The unintentional irregularity causes among other things an additional increase of deflections and stresses in track structure elements, which lead to failures and wear of track elements. Such arising the longitudinal irregularity in track is the reason for various forms of contact between sleeper and ballast. Track stiffness in unloaded state (without forces from trains) causes that the sleepers in various ways rest on the ballast. The analysis of load transfer from wheel by rail to the railway sleeper allows for visualizing the effects of such irregularity for railway track. Furthermore a shape of arising irregularity causes the decrease of train wheel traction efficiency understanding as the degree of its tractive adhesion utilization resulting from static loads. In paper an experimental analysis of arising irregularity in CWR track during its operating is enclosed.
\end{abstract}

Keywords: CWR track; vertical irregularities in track

\section{Introduction}

Condition of the railway track and its shape and location, described by the geometrical parameters, is gradually changed during operation. Changes in the geometric position of the track is followed mainly due to the load of vehicles, change its support and work performed in the track (raising track, ballast cleaning). The resulting inequality operated circuit cause a significant change in working conditions cooperating loaded elements of the track (rail, sleeper, ballast). The cause of track deformation is a diversity of characteristics track support in its various sections, formed as a result of irregular subsidence ballast during the operation [8], increased strain, especially the so-called weak subgrade, or the occurrence of the subgrade swelling soils. As a result of forming the inequalities created a different form of contact with the base layer of ballast. Track stiffness in the unloaded condition (without pressure from the vehicle) causes the backing to varying degrees based on the ballast. In the worst case it may complete lack of contact with the base ballast. Such areas because of lack of contact with the quarry ground track are particularly dangerous for the stability of the track contactless e.g. in summer during periods of longitudinal compressive forces. Moreover, from the point of view of working conditions of rail track wear or deformation of one element significantly worsens the working conditions of other, resulting the destruction, unfortunately, of the entire surface.

The main aim of this work is the issue related to the impact generated static deformation work loaded contactless railway track in the vertical plane (in the form of rail deflection). Indicated a significant change in operating conditions as a result of track operated primarily produced in the inequality. We analyzed the theoretical and experimental unintentional 
inequality in contactless railway track produced during its operation. We conducted field research in a real railway track, which provokes a local imperfection simulating short inequalities arising in operated railway track.

\section{Inequalities in contactless railway track}

In actual railway track there is a local path loss of contact with the ground locally deformed, and thus the formation of certain sections of the length of the gaps between the sleepers and the ballast $[2,3,4,5,16,17]$. The number of these gaps and range grow with time operation of the track. Load fleet restores lost contact with the ground track, but the phenomenon is accompanied by an increase in dynamic interactions of rolling stock on the track, depending on the size of the cavities and the speed of the rail vehicle. The formation of gaps in the track also creates unfavourable conditions for supporting the grate track, which negatively affects the stability of track operated contactless. Unequal locally elastic substrate, on which rests a contactless railway track as a result of compressive forces can cause additional deflection rail. In the case of convex cross level of compression waves may occur locally to lose track contact with the ground (fig. 1) [16,17]. The shape of local inequality is described by the equation:

$$
y_{p}=\frac{f_{p}}{2} \cdot\left(1-\cos \left(\frac{2 \cdot \pi \cdot x}{l_{p}}\right)\right)
$$

where:

$f_{p}$ - arrow of vertical deformation wave,

$l_{p}$ - vertical deflection wave length.

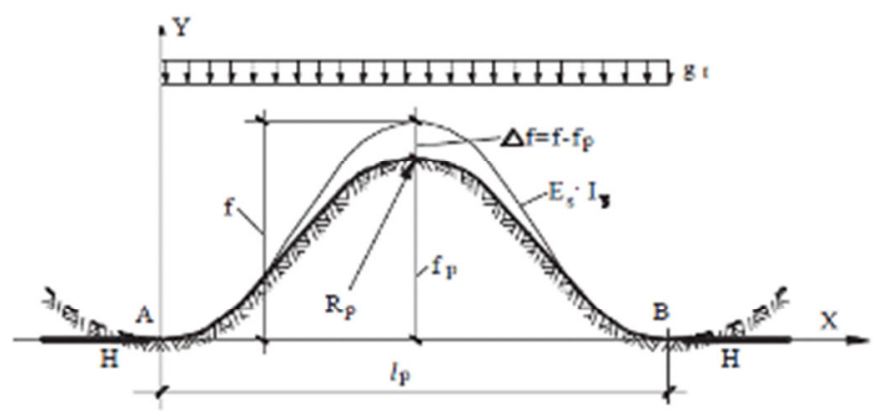

1. Vertical deformation of the track described by sinusoid [16]

Measured values $f_{P}$ and $l_{P}$ allows to check the condition of the track safety with the use of graphs in fig. 2. The measurement of the vertical deformation is very difficult to determine in a real railway track. Most often we are already observing the form of the deformation of the track rail in the vertical plane, which safety can be assessed on the basis of theoretical considerations. The analysis of such a case (included in [16]) allows the graph indicate ranges of safe wavelengths $l_{P}$ with the arrow inequality $f_{P}$ (provided full contact with the ground track), made for track-type 60E1 with wooden sleepers and concrete. These charts can be used also for track-type 49E1 [16]. 


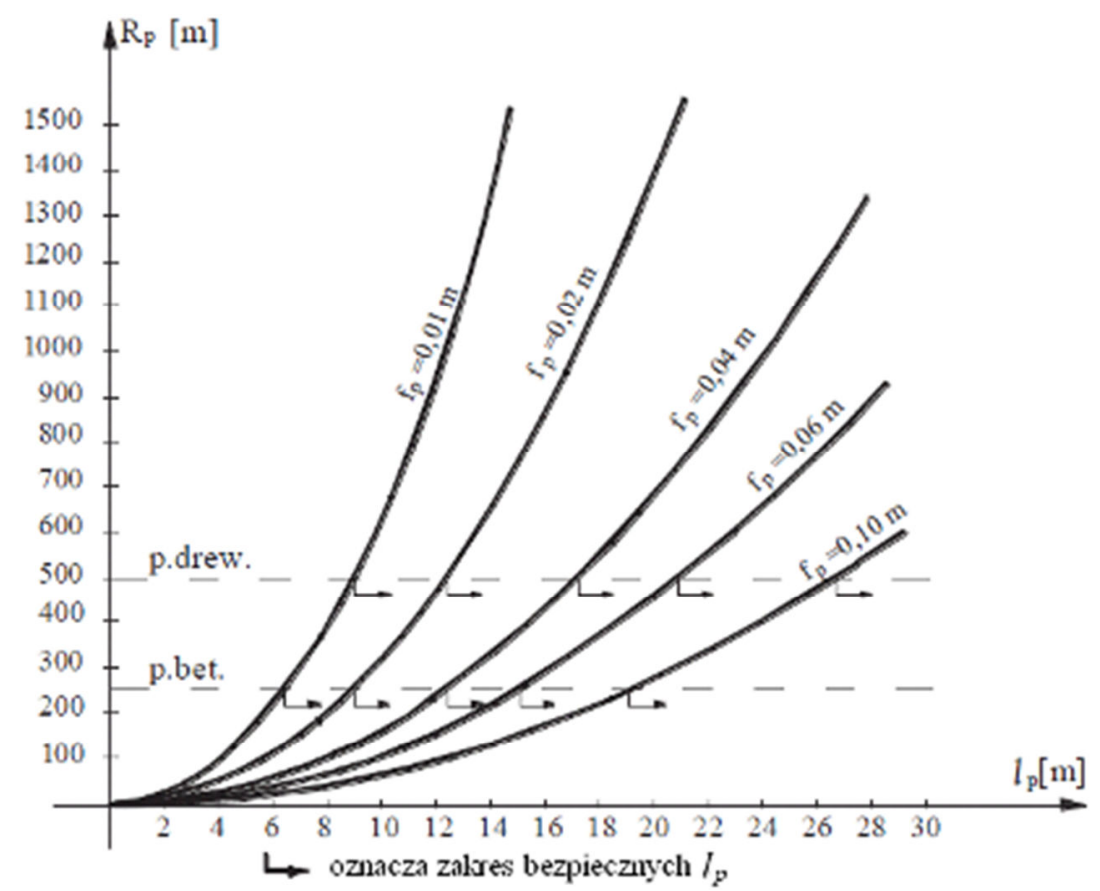

2. The theoretical range of safe wavelengths $l_{P}$ with the arrow $f_{P}$ inequality [16] thorium heat treated strength, compressive:: $H_{t}=1,67[\mathrm{MN}]$ (rails 60E1 at $\Delta \mathrm{t}=45\left[{ }^{\circ} \mathrm{C}\right]$ ) $H=m \cdot H_{t}, m=1,1$ (the influence braking forces of the rolling stock)

Explanations for figure 2:

$$
R_{p}=\frac{l_{p}^{2}}{2 \cdot \pi^{2} \cdot f_{p}}
$$

where:

$R_{p}$ - ray of vertical irregularities,

$f_{p}$ - arrow of vertical deformation wave,

$l_{p}$ - the wavelength of deformation,

$$
R_{d}=0,5 \cdot \frac{m \cdot n \cdot H_{t}}{g_{t}}
$$

where:

$R_{d}$ - allowable ray of vertical irregularities of the substrate depending on the type of primer,

gt - the weight of track,

$n$ - security factor,

$m-$ as above,

obtained: $R_{d}=459$ [m], adopted (due to safety track): $R_{d}=500$ [m] (wooden underlays) and $R_{d}=239$ [m], adopted because of the safety of the track): $R_{d}=250$ [m] (concrete underlays). 


\section{A local deformation of the rails and wheels surface}

The main reason causing damage to the surface of the rolling wheel and rail stations are operational conditions (e.g. heavy braking) [6,7]. During braking the wheels tread heats up to high temperatures. This results layer lowering the yield strength in the surface, and considerable pressure in the contact zone of the wheel-rail interface results in local plastic deformation of the material. With its rapid cooling creates a brittle martensite. After cooling, the wheels in the surface layer generate large tensile residual stresses leading to minor surface cracks.

The size of the dynamic interactions have a very significant impact irregularities track (primarily short vertical irregularities) being the cause of increasing stresses in the subgrade even 2.6 times compared to static loads. In the case of local deformation of the running surface of the rail, track point where the impact is greatest, is always ahead of the middle irregularities in the direction of the vehicle (fig. 3).

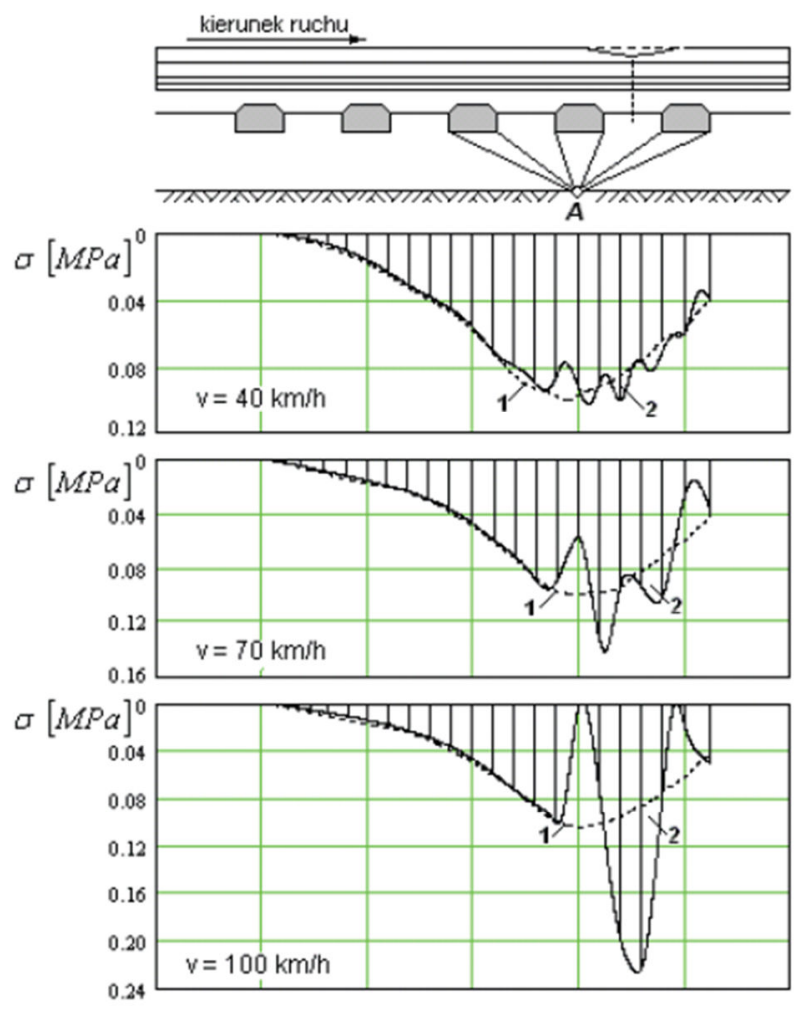

3. Stresses under the ballast [15]

1 - rail without irregularities, 2 - rail with an average slope inequality $10 \%$

In case of an average inclination of track irregularities smaller than $1 \%$ at length irregularities at least 2 [m], the additional load does not occur [15]. Inequality ARL and drive wheels by such inequality are considered in [18]. Flat wipe the rim of the wheel sets have a direct impact on the stresses generated in the surface, especially in the rails. This wipe is a major cause of cracking rails, especially in winter time at low temperatures [11]. With the weave of adverse factors (low temperature, poor suspension of the railway carriage emphasis wheels on the rail) can cause massive damage to the rails. The stresses in the rail caused flat wiping wheels depends on many factors, the most important are [13,19]:

- depth of wipe,

- axle load,

- the state of railway carriage suspension,

- elasticity of the track substrate, 
- speed.

During the ride, wheel with flat spot can be divided into three characteristic phases of its contact with the rail:

1) during the wheel passage within the flat places emphasis on rail decreases (fig. 4a),

2) at the so-called critical speed of about $30 \mathrm{~km} / \mathrm{h}$ occurs the phenomenon of loss wheel with rail contact (fig. $4 \mathrm{~b}$ ),

3) in the last phase of rotation of the wheel struck the edge of the flat space in the rail (fig. 4c).

a)

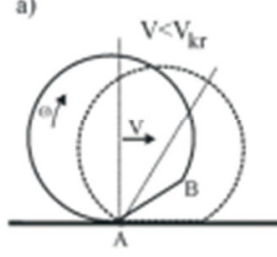

b)

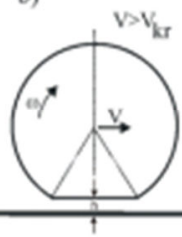

c)

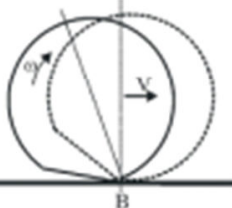

4. Phase of wheel movement with a flat spot on the wheel [10]:

a) with no loss of contact (the edge $A$ ), b) loss of contact, c) hitting the rail edge $B$

\section{Reducing the effectiveness of the wheel grip on deformed track}

Arising irregularities of the track cause abnormal rotation of the wheel. This affects the efficiency of the traction wheel understood as utilization of its adhesion resulting from the static pressure during operation [12]. For the case of wheel movement on the track unequal sinusoidal (fig. 5) we have: $\varsigma(l)=a \cdot \sin \left(\frac{2 \cdot \pi}{L}+\vartheta\right)$, where $\vartheta-$ the initial angle of phenomenon observation [12]; adopted $\vartheta=0$.

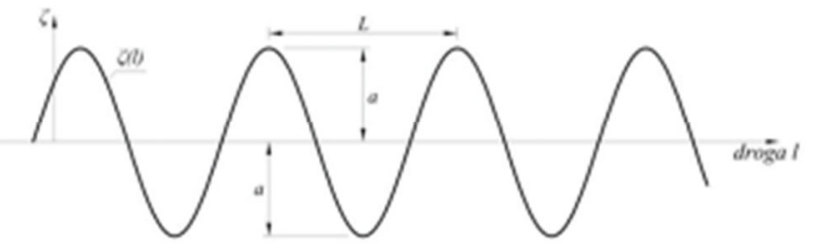

5. Inequality track described by sinusoid [12]

Such inequality track described by sinusoid, reduces adhesion between wheel and rail [12], shown in figure. 6 :

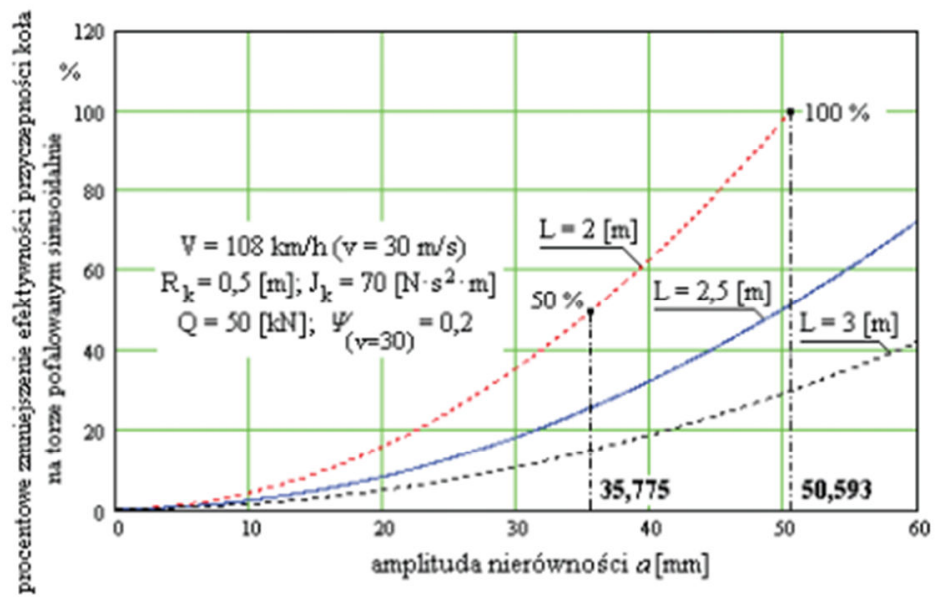

6. Reducing the effectiveness of the wheel grip on deformed track, where: $R_{k}$ - ray of the wheel; $J_{k}-$ the mass moment of wheel inertia [12]. 
At the wheel load on the rail $Q=50 \mathrm{kN}$ on length of $2[\mathrm{~m}]$ and the value of coefficient of adhesion: $\Psi_{(v=30)}=0,2$, we get a significant reduction in the efficiency of adhesion with an amplitude greater than $5[\mathrm{~mm}]$, a theoretical 50 percent lack of grip at $a_{g r}=35,775[\mathrm{~mm}]$, where:

$a_{g r}$ - border amplitude deformed track [12]. Increasing wheel pressure causes reduce this adverse event. A detailed description of the issues is contained in thesis [12].

\section{Increase of rolling stock impact on the track due to local course rail irregularities}

Moving along the irregular track fleet restores lost contact with the ground track, but the phenomenon is accompanied by an increase in dynamic interactions rolling stock on the track. The size of this increase depends primarily on the shape of the irregularities, and the resulting speed of the rail vehicle, and to a much smaller extent on the design of the suspension of the rail vehicle and the deformation of vehicle wheels $[9,14]$. Vertical deformation of the track are cosine shape (Fig. 7) [14], most often replaced by straight lines $A B$ i $B C$.

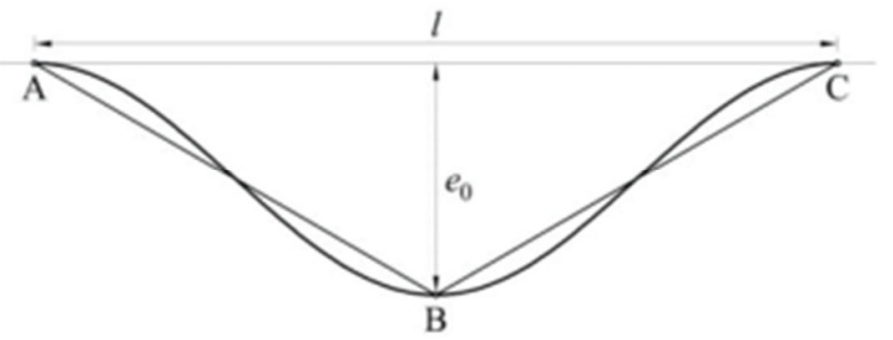

7. shape of the vertical irregularities of rail course [14]

$e 0-$ depth of irregularities, $l-$ length of irregularities

In calculation of the surface are adopted dynamic factors $k_{d}$ taking into account the impact of the local irregularities of the track, e.g. in the a formula [5]:

where:

$$
k_{d}=1+0,000085 \cdot \frac{e_{0}}{l} \cdot V^{2}
$$

$e_{0}-$ depth of irregularities $[\mathrm{mm}]$,

$l$ - length of irregularities [m],

$V$ - speed $[\mathrm{km} / \mathrm{h}]$.

On fig. 8 is showed dependence of the dynamic factor $k_{d}$ from length of irregularities $l$ for selected depth irregularities $e_{0}$ and speed $V$. 


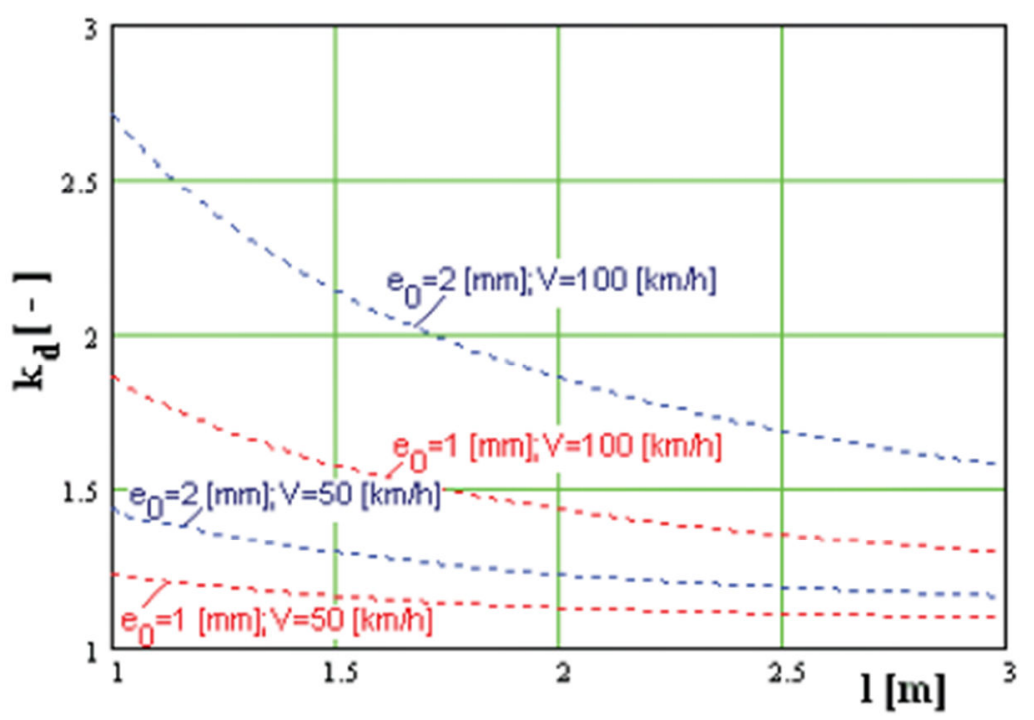

8. Dependence of dynamic factor $k_{d}$ (formula 2.4)

from length of irregularities $l$ for selected depth of irregularities $e_{0}$ and speed $V$

As shown in fig. 8 particular interaction increase passing rolling stock on the track, is followed by "short" bumps $l$ o „,big” depth $e_{0}$ (as well as the consumption of wavy rails). Particular importance takes, therefore, the quality of works in the track [1], described, e.g. a synthetic indicator of quality of the track $J$ (in thesis [1] have contained an example of a small increase in the value $J$ to about $0,6[\mathrm{~mm}]$ during 4 years of the track operation, with its initial value row $0,5[\mathrm{~mm}])$.

\section{The impact of the local surface irregularities on track work}

This paragraph presents an analysis of the track work within the local deformation. The relationship between the emerging strain and track changes in the value of deflection in the rail, which can be assessed only under the influence of the applied load of the locomotive. Described experimental studies done in the railway track, include the measurement of deflection of the rail under simulated heterogeneity in the substrate primers. Shown method of generating a strain in the track, and a way of measuring changes in specific necessary parameters to describe the work of rail track. This method, based on measurements on a loaded track, allows to describe the effects of changes in the conditions of the track support, demonstrating its usefulness to analyze the growth of deflections for the assumed shape of imperfections simulating short irregularities arising operated railway track.

Local vertical irregularity arising on the track usually has a random character, undesirable and unintended (fig. 9). Irregularity causes such areas lack of contact substrates with a top layer of ballast, which is especially dangerous for his work in the period of occurrence, e.g. large compressive forces.

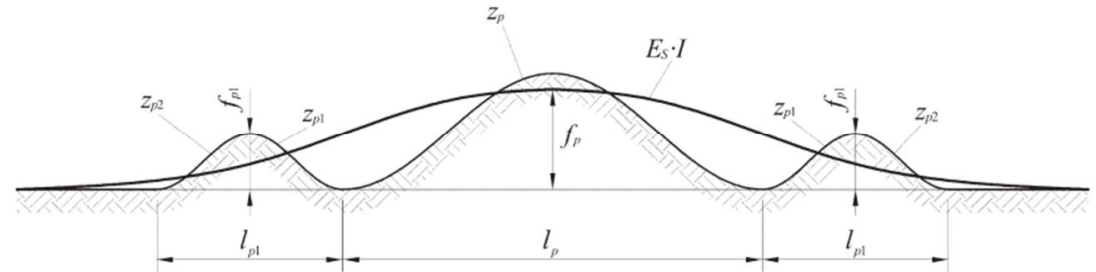

9. Examples of three irregularities substrate and the contact with the ground track frame with quarry

where: $z_{p}, z_{p 1}, z_{p 2}$ - the form of surface irregularities (formula 1),

$f_{p}, f_{p 1}, f_{p 2}$ - arrow adopted vertical deformation wave, 
$l_{p}, l_{p 1}, l_{p 2}-$ length of adopted vertical deformation wave, $E_{S} \cdot I-$ track stiffness (pairs of rails) in a vertical plane $\left[\mathrm{MNm}^{2}\right]$.

The consequence of the process of adapting to changing track conditions its support is to change the values of deflections and stresses in the cooperating elements of the frame track.

\section{Description of the proposed method of generating unintended deformation of the track}

In order to analyze the work loaded elements of the track on local irregularities performed fieldwork at the railway station Poznań-Franowo. The aim of the study was to analyze the unintended irregularities in the railway track by simulating irregularities in the form of changes in the conditions of the support rails in the analyzed cross-section of rail track (accepted measurement diagram shown in fig.10) [5].

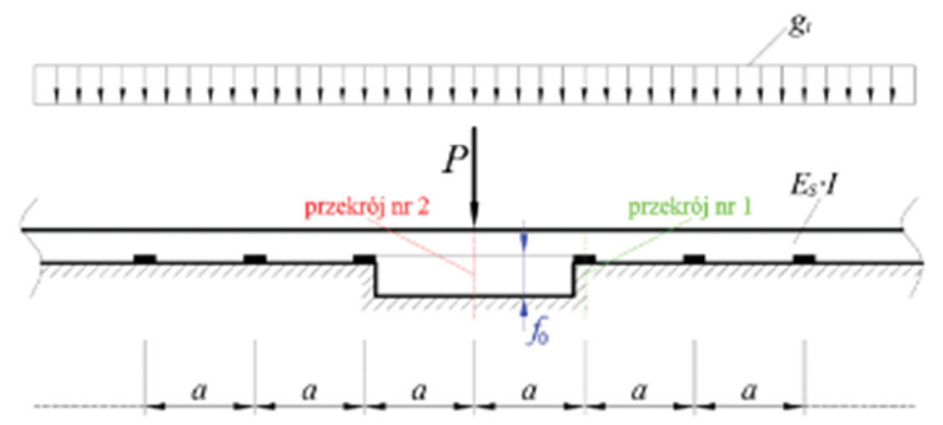

10. Diagram of induced irregularities in the railway track

$f_{0}$ - inequality caused in railway track [mm], $P$ - applied force $[\mathrm{MN}], E_{S} \cdot I$ - track stiffness

(pair of rails) in vertical plane $\left[\mathrm{MNm}^{2}\right], E_{s}$-Young modul steel rail; $g_{t}-$ weight of track

$[\mathrm{MN} / \mathrm{m}], a-$ spacing of underlays $[\mathrm{m}]$

In track was called the local irregularity by lowering the track by a specified value (parameter $f_{0}$ on fig. 10). Irregularity of the track obtained by loosening the fastening, raising track lift (without the stability of contactless track in the horizontal plane, in accordance with applicable regulations). Additionally, in order to ensure the stability of the track, increasing the track implemented gradually over a short distance railway track (as single or double sleeper spacing). Was followed by placement of metal plates between the rail and the pad, leaving the rails on the pad and re-attachment of rails to the sleepers. Value $f_{0}$ increased from $f_{0}=0 \mathrm{~mm}$ (the initial state of the track) to 1,2 i $3 \mathrm{~mm}$. During the measurements made 12 quasi-static low speed journeys using locomotive SM-42-448 (72 [t] on 4 axles $\rightarrow$ so 180 $\mathrm{kN} / \mathrm{axle}$ ). This allowed analysis of the track operation (and in particular the rail and surface) by measuring the deflection of both the rail and the sleeper. Due to a shared stretch of track testing, assembly equipment (fig. 11) was performed on the rail and concrete sleeper. For the analysis was used optical displacement measurement system GOM mbH (Gesellschaft für Optische Messtechnik, Technischen Universität Braunschweig), which applies in 3D digitalization (, e.g. In a coordinate measurement). The PONTOS used for 3D motion analysis, ensuring accurate $(0,001 \mathrm{~mm})$, contactless measurement of position, movement and deformation of the short measurement time (eg. 0.005 seconds). Advantage programs PONTOS Viewer version v6.3.0-5 by GOM mbH and catman Easy version 2.1 by HBM $\mathrm{GmbH}$. 


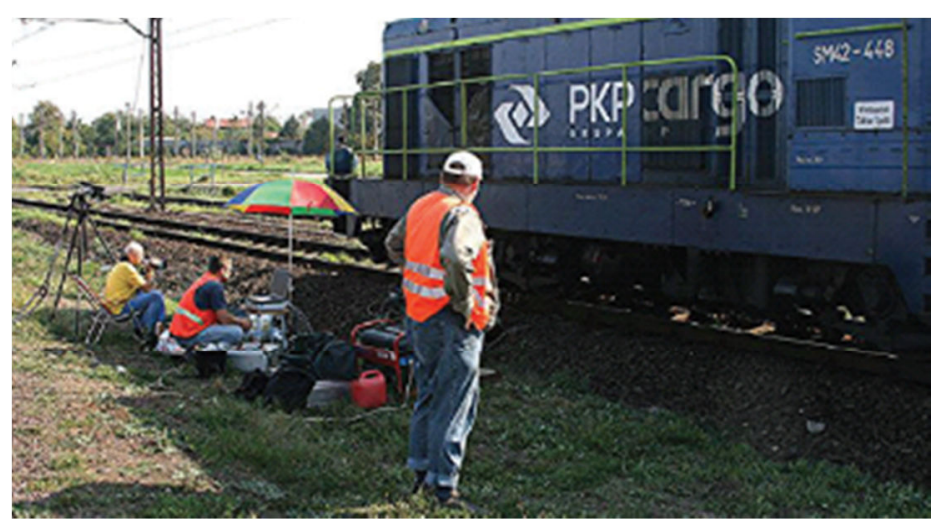

11. Measuring station for recording obtained measurements at the Poznań-Franowo station

\section{The results of deflections obtained during field research}

During the crossings generated by the locomotive's deformed railway track were measured deflection of rails and primer for consecutive 4-axle locomotives SM 42. Due to the short distance between sections 1 and 2 (equal spacing sleepers), it was assumed that the analyzed section of the track before testing has a rectilinear form (without preliminary irregularities).

In fig. 12 and 13 are shown deflection of the rail and the base for the simulated inequality track railway station Poznań-Franowo for the pressures of the next 4 axle locomotives [5]. Figures enable a scale assessment of changes in both the cross-section No. 1 and so No. 2 (from fig.. 10).
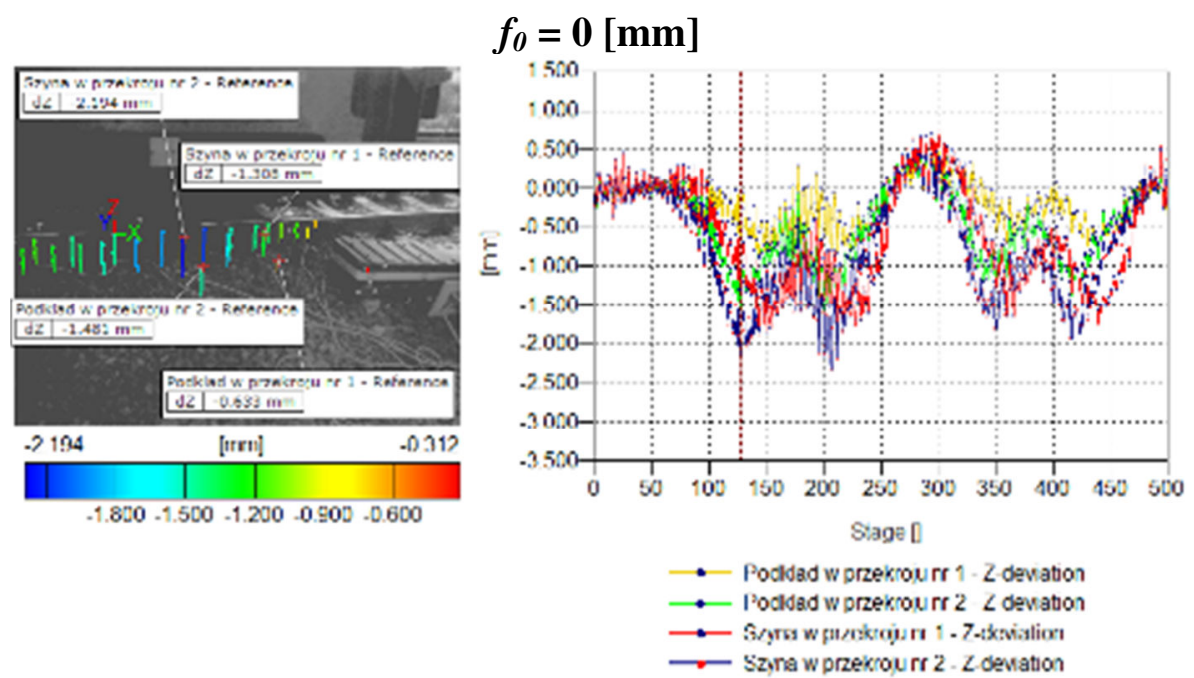

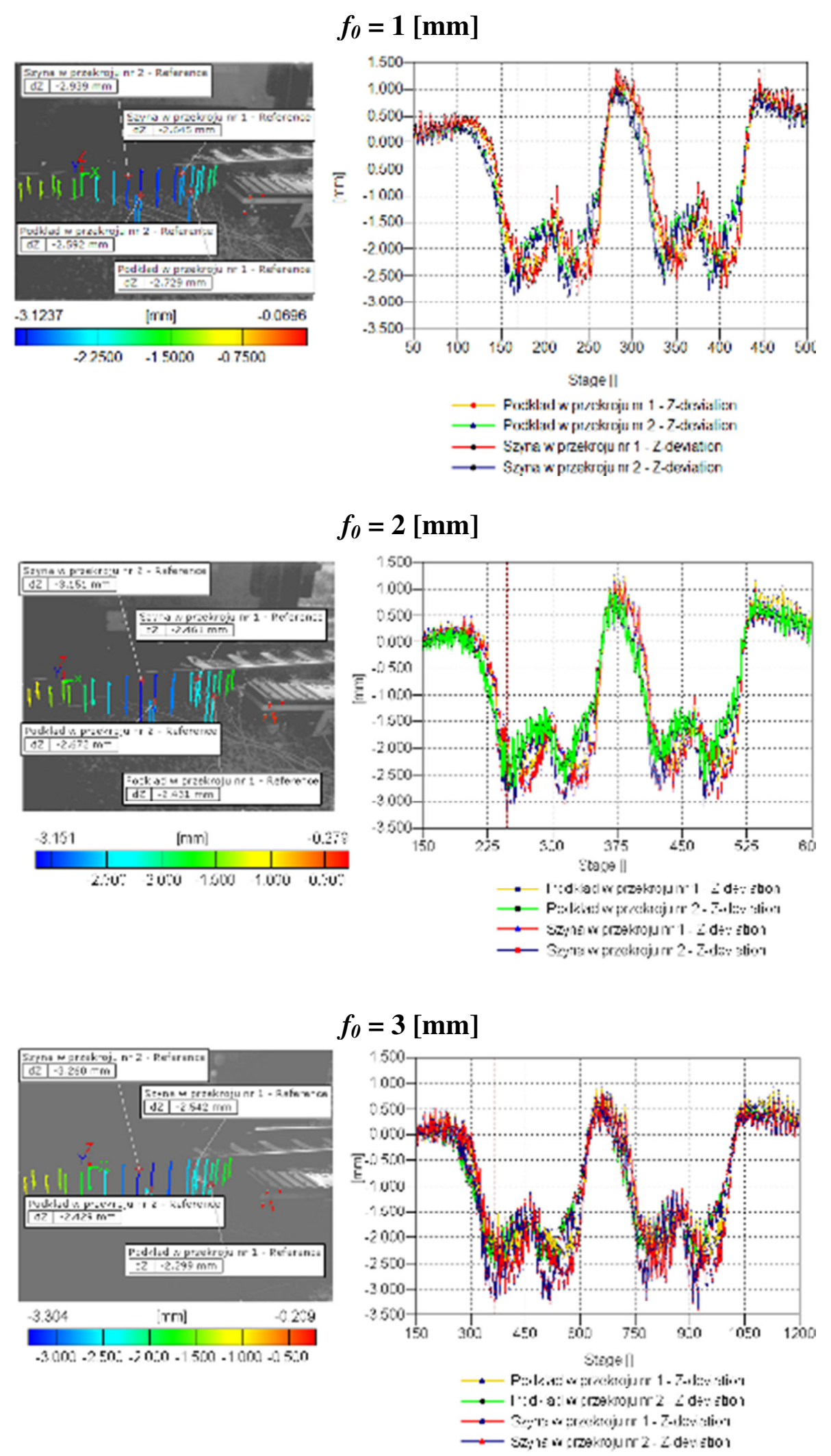

12. Rail and sleeper deflection caused as a result of irregularities in the railway track boundary conditions while changing the cross-section of the rail No. 2 ordinate - deflection of rail and sleeper; abscissa axis - further measurements at 0,005 [s] 
Changing the conditions of the support rail in cross-section No. 2 (scheme of figure. 10) Emphasis of axle No. 2 in section 1 - 2 axis Emphasis of axle No. 2 in section 2 - 2 axis
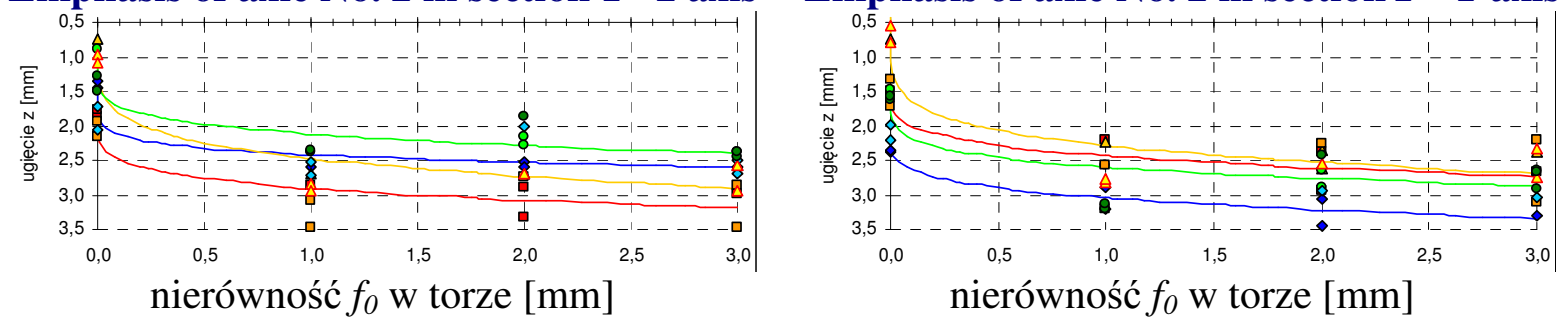

- ugięcie szyny $\mathrm{w}$ przekroju $\mathrm{nr} \quad 1$ : $z_{1}^{s z}\left(f_{0}\right)=1,1741 \cdot\left(f_{0}\right)^{0,1928}+1,7374$,

- ugięcie szyny w przekroju nr 2: $z_{2}^{s z}\left(f_{0}\right)=1,0235 \cdot\left(f_{0}\right)^{0,1495}+1,3963$,

- ugięcie podkładu w przekroju nr 1: $z_{1}^{\text {pod }}\left(f_{0}\right)=1,7509 \cdot\left(f_{0}\right)^{0,2017}+0,7219$,

- ugięcie podkładu w przekroju nr 2: $z_{2}^{\text {pod }}\left(f_{0}\right)=1,0034\left(f_{0}\right)^{0,2245}+1,1202$.

The following signs were used:
- Szyna przekrój 1 z kier. A
- Szyna przekrój 2 z kier. A
口 Szyna przekrój 1 z kier. B
$\diamond \quad$ Szyna przekrój 2 z kier. B Szyna w przekroju 1 _Lzyna w przekroju 2
$\Delta \quad$ Podkład przekrój 1 z kier. A
$\Delta \quad$ Podkład przekrój 1 z kier. B
Podkład w przekroju nr 1

○ Podkład przekrój 2 z kier. A

- Podkład przekrój 2 z kier. B

13. Examples of the deflection rail and sleeper caused as a result of irregularities in the railway track (emphasis of locomotive axle No. 2)

\section{The results discussion of the studies and obtained parameters of the railway track job description}

On figures (12 and 13) simulated arrows inequality $f_{0}$ caused in the track change significantly burdened the work of the superstructure elements. Especially in the relevant section 2 can be seen a big impact on these inequalities working railway track. And so: the diagram in fig. 10, in the absence of deformation in the track $\left(f_{0}=0 \mathrm{~mm}\right)$, rail deflection are about $2 \mathrm{~mm}$ (e.g. the two axle locomotive stress value was obtained $1,996 \mathrm{~mm}$ ). At $f_{0}=3 \mathrm{~mm}$ deflection of rail increases to $3.5371 \mathrm{~mm}$, which is about $77.2 \%$, and the deflection of the substrate is increased from 1.4373 to $2.8731 \mathrm{~mm}$, which is as much as $99.89 \%$. Increasing rail deflection and primer can be clearly seen in figure. 13.

Fig. 14 and table 1 show the experimental and theoretical (for substrate 1 - parameter) rails settlement and coefficients of empirical and theoretical calculation for the deflection rail $\left(K_{i}\right.$ i $\left.U\right)$ in cross-section No. 2 due to the force derived from the axis No. 2 locomotive. 
Tab. 1. The deflection rail in section No. 2 as a result of irregularities in the track $f_{0}-$ axle load No. 2

\begin{tabular}{|c|c|c|c|c|c|c|c|c|c|}
\hline \multicolumn{10}{|c|}{ podłoże 1 -parametrowe $k_{3}^{s z}=26,605[\mathrm{MPa}]$} \\
\hline $\begin{array}{c}\text { nierównoś } \\
\text { ć } \\
\text { w torze } \\
f_{0}[\mathrm{~mm}]\end{array}$ & $\begin{array}{c}z_{p o m} \\
{[\mathbf{m m}]}\end{array}$ & $\begin{array}{c}z_{\text {teor }} \\
{[\mathbf{m m}]} \\
\mathrm{MES}\end{array}$ & $\begin{array}{c}z_{k \neq 0} \\
\left(z_{\text {teor }}-f_{0}\right) \\
{[\mathrm{mm}]}\end{array}$ & $\begin{array}{l}z_{\text {teor }} \\
{[\mathbf{m m}]} \\
\text { sbval }\end{array}$ & $\begin{array}{c}U_{\text {zast }}^{\text {teor }} \\
{[\mathbf{M P a}]}\end{array}$ & $\begin{array}{c}K_{p o m} \\
{[\mathbf{k N} / \mathbf{m m}} \\
]\end{array}$ & $\begin{array}{c}K_{\text {teor }} \\
{[\mathbf{k N} / \mathbf{m m}} \\
]\end{array}$ & $\begin{array}{c}P_{k=0} \\
{[\mathbf{k N}]}\end{array}$ & $\begin{array}{c}P_{k \neq 0} \\
{[\mathbf{k N}]}\end{array}$ \\
\hline $\mathbf{0}$ & $\begin{array}{c}1,996 \\
1\end{array}$ & $\begin{array}{c}2,031 \\
2\end{array}$ & - & $\begin{array}{c}2,035 \\
5\end{array}$ & $\begin{array}{c}26,605 \\
*\end{array}$ & 45,0879 & 44,3088 & - & 90 \\
\hline 1 & $\begin{array}{c}2,887 \\
2\end{array}$ & $\begin{array}{c}2,721 \\
7\end{array}$ & 1,7217 & $\begin{array}{c}2,796 \\
2\end{array}$ & 17,526 & 31,1721 & 33,0676 & $\begin{array}{c}16,6 \\
8\end{array}$ & $\begin{array}{c}73,3 \\
2\end{array}$ \\
\hline 2 & $\begin{array}{c}3,054 \\
1\end{array}$ & $\begin{array}{c}3,237 \\
1\end{array}$ & 1,2371 & $\begin{array}{c}3,285 \\
5 \\
\end{array}$ & 14,181 & 29,4686 & 27,8027 & $\begin{array}{c}34,5 \\
1 \\
\end{array}$ & $\begin{array}{c}55,4 \\
9 \\
\end{array}$ \\
\hline 3 & $\begin{array}{c}3,537 \\
1\end{array}$ & $\begin{array}{c}3,689 \\
9\end{array}$ & 0,6899 & $\begin{array}{c}3,684 \\
9\end{array}$ & 12,099 & 25,4446 & 24,3909 & $\begin{array}{c}54,1 \\
9\end{array}$ & $\begin{array}{c}35,8 \\
1\end{array}$ \\
\hline
\end{tabular}

*) value obtained from the locomotive test ride for $f_{0}=0[\mathrm{~mm}]$ where:

$z_{\text {pom }}$; $z_{\text {teor }}$ - deflection of rail (experimental and theoretical) generated as a result of irregularities in the track,

$z_{k \neq 0}-$ deflection of rails after the contact with the priming ground,

$U_{\text {zast }}^{\text {toor }}$ - replacement and theoretical support rails for the case of "weak" its support (fig. $10)$

$K_{\text {pom }} ; K_{\text {teor }}-$ coefficients of empirical and theoretical calculation for the deflection of the rail scheme for irregularities of the fig. 10,

$P_{k=0}, P_{k \neq 0}$ - properly: part of the force transmitted to the wheels on the rail track causing contact with the ground and the remainder of the force transmitted to the wheels on the rail causing deflections and stresses the track after contact with the ground for the case of "weak" support track,

$k_{3}^{s z}$ - coefficient of substrate 1 -parameter (obtained from the locomotive test ride for $\left.f_{0}=0[\mathrm{~mm}]\right)$,

$z_{\text {teor }}$ sbval - Theoretical deflection of rails due to irregularities generated in the track (calculated as the boundary value problem using boundary conditions leading to the initial problem [5]).

To perform the calculations used created FEM model, treating it as a weighty Bernoulli-Euler beam on the elastic substrate 1-parameter, in detail described in [5] Using this calculation model set value: $U_{z a s t}^{\text {teor }}=26,605[\mathrm{MPa}]$ (obtained from a locomotive test drive for $f_{0}=0[\mathrm{~mm}]$ ). Another value $U_{z a s t}^{\text {teor }}$ for the next inequality in track: $f_{0}=1,2$ i 3 [mm] set this model using obtained values $z_{\text {pom }}$ for section 2 from fig. 10. Calculated in this way parameter $U_{\text {zast }}^{\text {toor }}$ describes the "weak" support the track, which "replaces" gradually increasing the initial lack of contact with the ground track in section No. 2. Similarly, using the numerical model was set theoretical value of the portion of the force transmitted to the wheels on the rail track causing contact with the ground $\left(P_{k=0}\right)$ and the remainder of the force transmitted to the wheels on the rail causing sagging after contact with the ground track for the case of "weak" support track $\left(P_{k \neq 0}\right)$. 


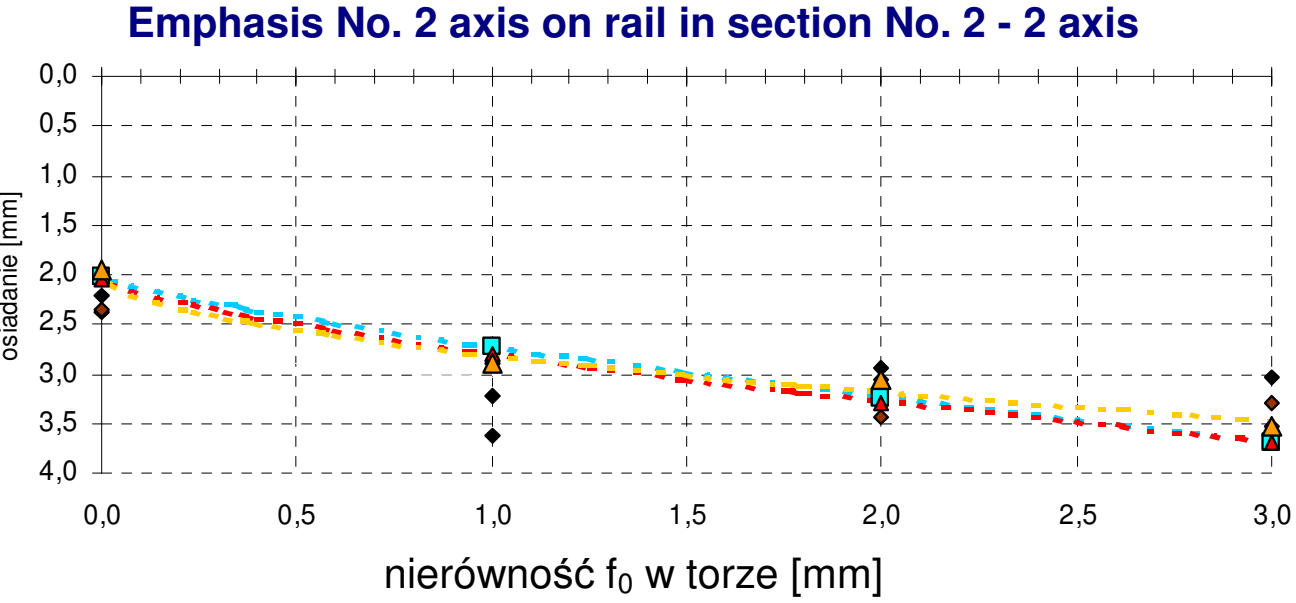

$z_{2}^{s z}\left(f_{0}\right)=0,81585 \cdot\left(f_{0}\right)^{0,53554}+2,00168, z_{2}^{s}\left(f_{0}\right)=0,69303 \cdot\left(f_{0}\right)^{0,79543}+2,03087, z_{2}^{s z}\left(f_{0}\right)=0,76512 \cdot\left(f_{0}\right)^{0,70117}+2,03501$

14. Theoretical and experimental settling rails as a result of imbalances caused by in railway track(scheme from fig. 10) in section No. 2 for locomotives pressure axle No. 2

Description of symbols:

$z_{2}^{s z}\left(f_{0}\right)$ - deflection of rail in the analyzed section No. 2 (fig. 10),

- - values from the experimental measurements using a locomotive SM42 (Poznań Franowo),

$\Delta-$ values calculated from the formula describing the fieldwork,

$\mathbf{A}$ - theoretical values calculated using the procedure sbval (graphs made using the command Bulstoer program Mathcad, which use a Bulirsch-Stoer method),

$\square$ - theoretical values (substrate 1 -parameter).

\section{Conclusion}

1. Based on the analysis can conclude that:

The full path to the resilient contact substrate for the formation of unevenness in the track, is provided to secure a wavelength range of $l_{p}$ at a specific arrow inequality $f_{p}$ (fig. 2).

2. Deforming the sinusoidal path causes abnormal movement of the rotating wheel, affecting the traction efficiency of adhesion (scale changes can be assessed on the basis of fig. 6).

3. In case of irregularities in the track in the form of heterogeneity in the substrate primers author studied caused unintended inequality of known initial values wavelength deformation and arrows (fig. 10) The impact of this inequality (as to reveal only after application of the load) was analyzed in experimental work. It was found that caused inequality of inequality arrow $f_{0}$ in track changes in a significant way work loaded superstructure elements (height deflection of up to approx. 78\%) A similar form of deformation in the track (vertical inequality) is created during its operation.

4. The proposed method of generating imbalances in the railway track is non-destructive causing imperfections in the track. It inviolate primary contact rails and the base substrate The presented method is particularly useful in studies of the support track and might be the right tool for the evaluation of the loaded elements of the railway track. 


\section{Source materials}

[1] Bałuch H.: Syntetyczne metody oceny nawierzchni kolejowej. Problemy Kolejnictwa, Zeszyt 166, 2015,

[2] Bednarek Wł.: Local unevenness of lengthwise profile influence on stability conditions of continuous welded rail track. Foundations of Civil and Environmental Engineering, Poznań University of Technology, No. 10, 2007,

[3] Bednarek W.: Wpływ lokalnych nierówności profilu podłużnego na warunki stateczności bezstykowego toru kolejowego. Archiwum Instytutu Inżynierii Lądowej 3/2007, XIV Konferencji Naukowo-Technicznej „Drogi Kolejowe 2007”, PoznańRosnówko, 2007,

[4] Bednarek W.: Local subgrade unevenness of lengthwise profile influence on work conditions of CWR track. Foundations of Civil and Environmental Engineering (FCEE), Poznań University of Technology, No. 15, 2012,

[5] Bednarek Wł.: Wpływ pionowych odkształceń nawierzchni i podtorza na pracę toru bezstykowego. Rozprawy nr 506, WPP, Poznań 2013,

[6] Bogacz R., Świderski Z.: Uszkodzenia eksploatacyjne szyn kolejowych wywołane wzajemnym, dynamicznym oddziaływaniem pojazdów szynowych z torem. Problemy Kolejnictwa, z. 136, 2002,

[7] Bogacz R., Świderski Z.: Symulacja warunków eksploatacyjnych powodujących uszkodzenia powierzchni tocznych kół i szyn kolejowych. Symulacja w Badaniach i Rozwoju, Vol. 1, No. 2, 2010,

[8] Czyczuła W.: Eksploatacyjna stabilność drogi kolejowej. Monografie Politechniki Krakowskiej, nr 126, Kraków 1992,

[9] Esveld C.: Modern railway track. Second Edition, Delft 2001,

[10] Lesiak P., Podsiadło R.: Symulacyjne badania dynamicznego oddziaływania koła z płaskim miejscem na szynę $w$ środowisku UNIVERSAL MECHANIZM LOCO. Logistyka, 6, 2011,

[11] Łoś M.: Wpływ temperatury na pracę toru kolejowego. Wydawnictwa Komunikacji i Łączności, Warszawa 1974,

[12] Madej J.: Teoria ruchu pojazdów szynowych. Oficyna Wydawnicza Politechniki Warszawskiej, Warszawa 2004,

[13] Mazilu T.: A Dynamic Model for the Impact between the Wheel Flat and Rail. U.P.B. Sci. Bull., Series D, Vol. 69, No. 2, 2007,

[14] Skrzyński E.: Wpływ dużego obciążenia ruchem oraz zwiększonych szybkości pociągów na pracę podtorza. Problemy Kolejnictwa, nr 67, 1975,

[15] Skrzyński E., Sikora R.: Kolejowe budowle ziemne - tom I. WKiŁ, Warszawa 1990,

[16] Szumierz W.: Wpływ nierówności profilu na stateczność toru bezstykowego. Przegląd Kolejowy, nr 5, 1993,

[17] Szumierz W.: Zagadnienie stateczności eksploatowanego toru bezstykowego. Przegląd Kolejowy, nr 4, 1997,

[18] Timoshenko S.: Method of analysis of statical and dynamical stresses in rail. Proceeding of the Second International Congress for Applied Mechanics, Zurick, Switzerland 1926,

[19] Zhu J.J., Ahmed A.K.W., Rakheja S.: An Adaptive Contact Model for Simulation of Wheel-rail Impact Load due to a Wheel Flat. 13th National Conference on Mechanisms and Machines (NaCoMM07), IISc, India 2007, 